\title{
Phytopigments, Proline, Chlorophyll Index, Yield and Leaf Nitrogen as Impacted by Rootstock, Training System, and Girdling in “Aztec Fuji” Apple
}

\author{
Esmaeil Fallahi $^{*}$, Shahla Mahdavi', Clive Kaiser ${ }^{2}$, Bahar Fallahi' ${ }^{1}$ \\ ${ }^{1}$ Pomology and Viticulture Program, Department of Plant Sciences, Parma Research and Extension Center, University of Idaho, \\ Parma, USA \\ ${ }^{2}$ Umatilla County Extension, Oregon State University, Milton-Freewater, OR, USA \\ Email: *efallahi@uidaho.edu
}

How to cite this paper: Fallahi, E., Mahdavi, S., Kaiser, C. and Fallahi, B. (2019) Phytopigments, Proline, Chlorophyll Index, Yield and Leaf Nitrogen as Impacted by Rootstock, Training System, and Girdling in "Aztec Fuji" Apple. American Journal of Plant Sciences, 10, 1583-1598.

https://doi.org/10.4236/ajps.2019.109112

Received: August 15, 2019

Accepted: September 14, 2019

Published: September 17, 2019

Copyright $\odot 2019$ by author(s) and Scientific Research Publishing Inc. This work is licensed under the Creative Commons Attribution International License (CC BY 4.0).

http://creativecommons.org/licenses/by/4.0/

cc) (i) Open Access

\begin{abstract}
World overpopulation, scarcity of water and finite arable land mandate a more efficient use of these natural resources. To remain sustainable, modern-day apple (Malus domestica Borkh.) fruit production utilizes high-density orchards on semi-dwarfing, precocious rootstocks. Nonetheless, little attention has been paid to the use of size-controlling practices such as trunk girdling in these modern orchard systems. The impact of two rootstocks, two tree architecture (training) systems, and three levels of girdling (in spring) on chlorophyll index (CI), proline, chlorophyll content (Chl; $\mathrm{a}, \mathrm{b}, \mathrm{a}+\mathrm{b}$ ), carotenoids, anthocyanin, yield, fruit weight and leaf nitrogen (N) in "Aztec Fuji" were studied in 2015 and 2016. Trees on "Bud 9" had up to 5\% higher chlorophyll indices in leaves on side branches than those on "Nic 29" at each sampling time in 2015 and 2016. However, trees on "Nic 29" had up to $5.5 \%$ chlorophyll index in terminal

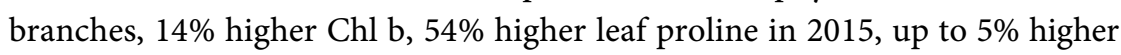
leaf nitrogen $(\mathrm{N})$ in 2015 and 2016, 82\% higher yields in 2015, and up to 7\% higher fruit weight in 2015 and 2016 than those on "Bud 9". Trees trained into a central leader (CL) architecture had up to $6 \%$ higher chlorophyll index and $4 \%$ higher leaf $\mathrm{N}$ in terminal branches 2015 and 2016, 43\% more terminal leaf proline content in 2015, but $13 \%$ less yield in 2016 than those with a tall spindle training (TS). Terminal leaves from trees receiving a bark girdling in 2015 (BG15) had up to $6.5 \%$ lower leaf $\mathrm{N}, 7 \%$ less chlorophyll index, and between $27 \%$ to $56 \%$ lower proline content than those from the ungirdled check and score girdled treatment in 2015 (SG15). Also, trees with BG15 and a bark girdling in both 2015 and 2016 (BG1516) treatments had significantly less leaf N concentration than all other treatments or the ungirdled check. Trees that were
\end{abstract}


score girdled in 2015 and repeat score girdled in 2016 (SG1516) had 21\% higher yield and $12 \%$ higher fruit weight than those that were ungirdled.

\section{Keywords}

Canopy Architecture, Cambium Ringing, Growth Control, High Density

Orchards, Malus x domestica

\section{Introduction}

World overpopulation mandates the efficient use of natural resources, including water and land. Establishment of high-density apple (Malus domestica Borkh) orchards, using new designs on dwarfing rootstocks have become popular in many progressive apple-producing regions around the globe. In apples, these new systems typically result in improved fruit quality and yield and rootstocks can influence several postharvest attributes, such as ripening, color, shape and fruit size [1] [2] [3] [4] [5]. It has been reported in the NC-140 (1984) cooperative planting that apple fruit ripening is negatively correlated with tree vigor, as the most dwarfing rootstocks resulted in the earliest ripening [1]. Rootstocks can also influence scion leaf and fruit mineral concentrations and thus, indirectly affect yield and fruit quality [6] [7] [8].

Selection of suitable tree architecture in a high-density orchard is mainly determined by rootstock vigor and soil type. Clements reported that performance of "McIntosh" and "Honeycrisp" apples on "Bud 9", "M.26" and "MM.106" rootstocks, with a central leader (CL), vertical axis (VA), or tall spindle (TS) tree architectures. In both cultivars, trees on "Bud 9" had the highest cumulative yield over 2008-2010 (during $3^{\text {rd }}$ through $5^{\text {th }}$ leaf), followed by those on "M.26" and "MM.106" rootstocks. In addition, their studies found that trees trained to TS had the highest production per hectare, followed by those with VA and CL [9].

Girdling is one of the most practical methods for inducing artificial stress [10]. This practice has been used in several deciduous and evergreen tree species [10]-[16]. Girdling is the removal of a circumferential strip of bark down to the vascular cambium, and if practiced during the early stages of growing season it temporally halts the flow of photosynthates from top of the tree to the root system. Girdling trunks or large branches enhanced fruit set and some quality attributes, particularly fruit color, when performed at specific growth stages on various fruit crops in some studies [14] [17] [18] [19] [20]. It has been suggested that girdling in fruit trees can increase carbohydrate supply during fruit maturation, leading to the enhancement of red coloration by increasing anthocyanin synthesis [21]. Girdling apple trees 10 days after petal fall only slightly improved red color in two of three cultivars but increased yellow background color development of fruit skins [22]. It has been reported that mid-summer trunk girdling increased red coloration and intensity both years and improved market-grade pack out in "Jonagold" apple [23]. This effect was not caused by advanced ma- 
turity. In that study, girdling reduced fruit size only on trees of low $\mathrm{N}$ status [23]. Post-bloom trunk girdling increased fruit set and flower bud formation and reduced vegetative growth on apple trees [24] [25] [26] [27]. It has been reported that fruit on girdled limbs of apples had higher fruit dry weight and dry weight concentration than on non-girdled limbs [28]. Leaf area on non-girdled limbs was unaffected by crop load but increased dramatically on girdled limbs with a crop load of less than one fruit per square centimeter limb cross-sectional area. These leaves also had a low photosynthetic rate, high stomatal resistance, and high internal $\mathrm{CO}_{2}[28]$.

The impact of girdling on yield and fruit quality attributes have also been studied in other fruit crops. In Argentina, girdling pear (Pyrus communis) trees increased yield in two seasons [29] Color on stone-fruits (Prunus spp.) was improved after trunk girdling at the pit-hardening stage [17] [18]. It has been reported that branch girdling, at the stage of rapid fruit growth, on "Hass" avocado (Persea americana) increased the fruit mass by 35\% [30]. Vine girdling in table grapes (Vitis vinifera) increased berry and cluster weight [12] [31] but decreased soluble solids concentration and titratable acidity [31].

Scoring is cutting through cambium layer without removing bark. In this method, flow of solutes through phloem will be stopped or slowed down for a shorter period than by girdling [12]. Other scientists observed that scoring and girdling increase yield without decreasing return bloom in "Triumph" persimmon (Diospyros virginiana) [32]. Scoring and girdling were equally effective in increasing fruit size in peach and nectarine (Prunus persica) [17] [33]; and loquat (Eriobotrya japonica) [34]. However, bark girdling may impair trees and vine health if callusing is slow or inadequate [12] [33]. In a study with orange ( $\mathrm{Ci}$ trus reticulate) trees, vascular connectivity of the phloem was re-established much faster after scoring than after girdling [35].

Chen et al. [36] reported that proline is one of four amino acids that rises during drought stress as you approach wilting [36] and that finding was later confirmed [37] [38] [39]. Yelenosky [39] found that proline is a major source of soluble nitrogen in citrus leaves. They also suggested that as a metal chelator and an antioxidant defense molecule, proline plays an important role in stress. Okumoto et al. [40] focused on understanding biochemical mechanisms of proline accumulation under stress conditions. They reported that proline is a major component of cell wall proteins and is regulated by developmental and environmental signals [40]. Other scientists observed a rise of proline in a wide range of plant species as a result of transcriptional and post-transcriptional regulation [38].

Measuring the amount of proline concentration appears to be a great way of monitoring artificial or natural stresses in several plants. When considering girdling as artificial stress for plants, considering amount of proline as a stress indicator factor in most plant species may be beneficial in evaluating girdling effects. Ibrahim et al. [41] reported that girdling branches or limbs decreased the chlorophyll a, b and total chlorophyll (Chl) concentrations and promoted caro- 
tenoids concentrations, fruit set and fruit yield of Washington navel orange leaves compared to the Control. Also, other scientists reported that the concentrations of Chl. $a$, Chl. b, and total chlorophyll $\mathrm{a}+\mathrm{b}$ decreased with girdling pistachio shoots [15]. Davie et al. [30] reported that leaves on girdled and scored branches of avocado without fruit showed a decrease in photosynthesis rate after treatment and stopped photosynthesizing 14 days after treatment. They also reported branches with fruit took longer to show a reduction in photosynthesis. Nevertheless, Rivas et al. [42] reported that girdling trunks of mandarin trees had no significant effect in total chlorophyll concentrations between control and girdled trees. However, other scientists reported that girdling had positive effects on total chlorophyll and chlorophyll (a) content in "Balady" mandarin leaves, but reduced chlorophyll (b) content [43].

Tang et al. [44] evaluated the effects of girdling on carbohydrate-induced senescence. They reported that girdling reduced chl. a, b, carotenoids, ratio of a:b and chlorophyll:carotenoids. In addition, Proietti et al. [45] reported that fruit dry mass increased, but chlorophyll concentration decreased in parallel with reduction of photosynthetic rate $\left(\mathrm{P}_{\mathrm{N}}\right)$ in olive trees in response to girdling.

Despite the use of dwarfing rootstocks and modern training systems in modern apple orchards, there is no report on the influence of tree girdling and scoring on the performance of apple trees under these conditions. Therefore, the objective of this experiment was to study the effect of two rootstocks, two training systems, and two levels of girdling on growth, yield, and fruit quality attributes at harvest-time and leaf nitrogen $(\mathrm{N})$ status in "Aztec Fuji" apple trees over 2015 and 2016 seasons compared to non-girdled controls.

\section{Materials and Methods}

\subsection{Orchard Establishment and General Cultural Practices}

The experimental orchard was established in the spring and early summer of 2010, on a north/south orientation, at the Parma Research and Extension Center, University of Idaho $\left(43.7853^{\circ} \mathrm{N}, 116.9422^{\circ} \mathrm{W}\right)$ on a sandy loam soil with an approximate $\mathrm{pH}$ of 7.3. The experimental site is a semi-arid climate with an annual precipitation of approx. $297 \mathrm{~mm}$. Climate conditions of this experimental site were almost similar to those in the Pacific Northwest [46]. General orchard cultural practices such as irrigation and thinning were reported in a different aspect of this comprehensive study elsewhere [5] [47] [48].

Total nitrogen of $60 \mathrm{~g} /$ tree as UAN 32 (urea and ammonium nitrate, 32\% N) was applied through the driplines. Each year, two fertigations of $30 \mathrm{~g} /$ tree $\mathrm{N}$ were made: one in late-May and second one two weeks later. Potassium was applied as $30 \mathrm{~g} \mathrm{~K} /$ tree as potassium oxide, via fertigation, once a year in late-May. Phosphorous, as monoammonium phosphate $\left(61 \% \mathrm{P}_{2} \mathrm{O}_{5}\right)$, was applied at the rate of $150 \mathrm{~g}$ of formulation to each tree-planting hole, only once at the time of planting. Micronutrients, particularly, iron and zinc, were sprayed twice in spring and once in early summer each year. Calcium $(\mathrm{Ca})$ was sprayed three times 
with cover sprays during spring every year.

\subsection{Rootstock and Tree Training Treatments}

"Aztec Fuji" trees on "M.9", RN 29 ("Nic 29") and Budagovsky 9 ("Bud 9") rootstocks (C \& O Nursery, Wenatchee, WA) were planted at $0.9 \times 3.90 \mathrm{~m}$ spacing with a north-south row orientation. "Snow Drift" crab apple (Malus $x$ "Snowdrift") on "M.26" EMLA rootstock (C \& O Nursery, Wenatchee, WA) was interplanted in each row as a pollinizer after every 10th "Aztec Fuji" tree. Trees were trained to either central leader (CL) or tall spindle (TS) during the dormant season in early-March each year. In trees with a CL training system, four main scaffolds were kept permanently and the other side beaches above these scaffolds were kept shorter at about $45^{\circ}$ angle to form a "Christmas-tree shape". Trees with a TS system were trained to have between 14 to 18 side branches, which were trained to $110^{\circ}$ from the vertical axis with tree ties. After the first year, only side branches with thicker than $1 / 2$ to $2 / 3$ diameter of the main leader were removed, leaving a $12 \mathrm{~cm}$-stub for regrowth. Tree leaders in both CL and TS were maintained at approx. $3.75 \mathrm{~m}$ in height.

\subsection{Girdling Treatments}

Each rootstock block contained 12 trees, where 6 of the adjacent trees in a row received TS training while 6 trees on the adjacent row received CL training. In 2015, trees were in full bloom on April 11, and girdling treatments were applied on April $27^{\text {th }}$. In 2015, paired trees of these 6 tree-plots received one of the three girdling treatments as follows: 1) Control or No Girdling (NOGD), where no girdling was applied; 2) Bark Girdling (BG15) at $30 \mathrm{~cm}$ above the graft union, where a complete 3 - $4 \mathrm{~mm}$ ring of bark with cambium was removed by cutting with a sharp knife so that xylem wood tissue was exposed; 3) Score Girdling (SG), where the bark of tree trunk was scored in a spiral pattern, going one and half turns around the tree trunk, from $30 \mathrm{~cm}$ above the bud union with a sharp linoleum utility knife. In 2016, trees were in full bloom on April 15 and girdling treatments were applied on May $16^{\text {th }}$. In 2016, the experimental arrangement was similar 2015, except for the fact that the second of each paired tree of the girdled treatments was not girdled or scored respectively. Where trees were girdled in 2016, this took place at approximately $6 \mathrm{~cm}$ above the 2015 bark girdling (BG15) site. This treatment was designated BG1516. Where trees were scored in 2016, this also took place approximately $6 \mathrm{~cm}$ above the 2015 score girdling site (SG15). Trees scored in both years were designated SG1516.

\subsection{Terminal and Side Branch Chlorophyll Index}

To determine chlorophyll index (CIs), four random terminal and side branches in each experimental tree were tagged and their final growth was measured in August, September and October 2015 and also June and October 2016, using a SPAD meter. CIs between 10 am and 2 pm were determined using equipment 
based on a new technology (Field Scout Chlorophyll Meter, Model CM 1000, Spectrum Technologies, Aurora, IL, USA) and determined according to the method described by Mahdavi et al. [49] [50]. The equipment uses the ambient and reflected 700 and $840 \mathrm{~nm}$ lights to calculate the relative CI. It measures conical viewing areas between 30 and $180 \mathrm{~cm}$ from lens. The equipment measures index of relative chlorophyll content ranges from 0 to 999.

\subsection{Leaf Nitrogen Measurements}

Thirty leaves were sampled from each tree at random from the middle of the current-season shoots in mid-August each year. Leaves were placed in a cooler and taken to the University of Idaho Pomology and Viticulture laboratories each year for analysis. Leaves were washed in a mild solution, containing $1 \% \mathrm{Li}$ qui-Nox anionic detergent (AlcoNox Inc., White Plains, NY, USA), rinsed in four different 25 - $\mathrm{L}$ containers of distilled water, and dried in a forced-air oven at $65^{\circ} \mathrm{C}$. Dried leaves were ground to pass through a 40 -mesh screen using a Cyclotec Sample Mill (Model 1093; Tecator, Hoganas, Sweden). Leaf N concentration was determined by combusting the dry leaf tissues using a LECO Protein/Nitrogen Analyser (Model FP-528; LECO Corp., St. Joseph, MI, USA).

\subsection{Yield and Fruit Weight Attributes}

Twenty fruits per tree were randomly sampled for quality evaluation and yield was recorded from each tree on October 17-20 during 2015-2016.

\subsection{Proline, Chlorophyll a, b, a + b, Carotenoids, Anthocyanin Measurements}

Free proline concentrations were determined according to the method described by Bates et al. [51]. Also, chlorophyll a, b and $\mathrm{a}+\mathrm{b}$ concentrations were measured according to the method described by Arnon [52]. Total leaf anthocyanin and carotenoid concentrations were measured determined according to the method described by Sims \& Gamon [53].

\section{Experimental Designs and Statistics}

The experimental design was a randomized complete block split-split plot (in both years) with two rootstocks as the main effects, two methods of tree training system as sub-plot, girdling treatments as sub-sub plots, and 4 blocks (replicates). Field data were collected throughout 2015 and 2016. At harvest leaf N concentration and individual tree yields were recorded. Analyses of variance was conducted using SAS (SAS Institute, Cary, NC, USA), with GLM and means were compared by least significant difference (LSD) at $\mathrm{P} \leq 0.05$.

\section{Results and Discussion}

\subsection{Interactions}

Other than a case between rootstock and tree architecture for yield per tree in 
2016, no significant interaction was observed between rootstock-training or rootstock-training-girdling treatments for any measurements in this study. Thus, only direct effects of rootstock, tree architectures, and type of girdling are reported in Tables 1-3.

Table 1. The influence of rootstock, canopy architectures, and cambium disconnection on terminal and side branch chlorophyll index, measured by SPAD meter in “Aztec Fuji” apple in 2015 and 2016.

\begin{tabular}{|c|c|c|c|c|c|c|c|c|c|c|}
\hline \multirow{3}{*}{ Treatment } & \multicolumn{6}{|c|}{2015} & \multicolumn{4}{|c|}{2016} \\
\hline & \multicolumn{2}{|c|}{ August 15} & \multicolumn{2}{|c|}{ September 9} & \multicolumn{2}{|c|}{ October 16} & \multicolumn{2}{|c|}{ June 30} & \multicolumn{2}{|c|}{ October 20} \\
\hline & Terminal & Side & Terminal & Side & Terminal & Side & Terminal & Side & Terminal & Side \\
\hline \multicolumn{11}{|l|}{ Rootstock } \\
\hline Nic 29 & $61.72 \mathrm{a}^{\mathrm{x}}$ & $54.30 \mathrm{~b}$ & $59.07 \mathrm{a}$ & $51.52 \mathrm{~b}$ & $59.46 \mathrm{a}$ & $53.00 \mathrm{~b}$ & $58.42 \mathrm{a}$ & $53.75 \mathrm{~b}$ & $58.95 \mathrm{a}$ & $50.49 \mathrm{~b}$ \\
\hline Bud 9 & $60.47 \mathrm{a}$ & $56.86 \mathrm{a}$ & $57.42 \mathrm{~b}$ & $52.78 \mathrm{a}$ & $56.36 \mathrm{~b}$ & $54.08 \mathrm{a}$ & $58.21 \mathrm{a}$ & $55.65 \mathrm{a}$ & $57.90 \mathrm{~b}$ & $51.31 \mathrm{a}$ \\
\hline \multicolumn{11}{|l|}{ Tree Training } \\
\hline Central Leader & $62.80 \mathrm{a}$ & $56.00 \mathrm{a}$ & $59.97 \mathrm{a}$ & $52.47 \mathrm{a}$ & 58.59 a & $54.45 \mathrm{a}$ & $58.73 \mathrm{a}$ & $54.32 \mathrm{a}$ & $57.97 \mathrm{a}$ & $49.65 \mathrm{a}$ \\
\hline Tall Spindle & $59.32 \mathrm{~b}$ & $55.16 \mathrm{a}$ & $56.48 \mathrm{~b}$ & $51.85 \mathrm{a}$ & $57.09 \mathrm{~b}$ & $52.60 \mathrm{a}$ & $57.98 \mathrm{~b}$ & $55.09 \mathrm{a}$ & $56.89 \mathrm{~b}$ & $51.94 \mathrm{a}$ \\
\hline \multicolumn{11}{|l|}{ Girdling $^{2}$} \\
\hline NOGD & $62.35 \mathrm{a}$ & $55.51 \mathrm{a}$ & $58.43 \mathrm{a}$ & $52.83 \mathrm{a}$ & $59.26 \mathrm{a}$ & $54.28 \mathrm{a}$ & $59.11 \mathrm{ab}$ & $55.03 \mathrm{ab}$ & $57.85 \mathrm{ab}$ & $51.99 \mathrm{ab}$ \\
\hline BG15 & $58.62 \mathrm{~b}$ & $53.42 \mathrm{~b}$ & $56.88 \mathrm{~b}$ & $50.48 \mathrm{~b}$ & $56.48 \mathrm{~b}$ & $51.66 \mathrm{~b}$ & $58.52 \mathrm{ab}$ & $55.85 \mathrm{a}$ & $58.09 \mathrm{ab}$ & $52.70 \mathrm{a}$ \\
\hline SG15 & $62.49 \mathrm{a}$ & $57.89 \mathrm{a}$ & $59.42 \mathrm{a}$ & $53.22 \mathrm{a}$ & 57.79 a & 54.59 a & $59.30 \mathrm{a}$ & $55.42 \mathrm{a}$ & $60.09 \mathrm{a}$ & $50.79 \mathrm{ab}$ \\
\hline BG1516 & . & . & . & . & . & . & $57.35 \mathrm{~b}$ & $52.50 \mathrm{~b}$ & $56.32 \mathrm{~b}$ & $48.65 \mathrm{~b}$ \\
\hline SG1516 & . & . & . & . & . & . & $56.78 \mathrm{~b}$ & $54.99 \mathrm{ab}$ & $57.65 \mathrm{ab}$ & $49.81 \mathrm{ab}$ \\
\hline
\end{tabular}

${ }^{z}$ Abbreviations: NOGD = no girdling (control); BG15 = bark girdling in 2015; SG15 = score girdling in 2015; BG1516 = bark girdling in 2015 and 2016; SG1516 = score girdling in 2015 and 2016. ${ }^{\mathrm{x}}$ Mean separation within columns in each group of treatments by LSD at $5 \%$ level.

Table 2. The influence of rootstock, canopy architectures, and cambium disconnection on leaf nitrogen (N) proline, chlorophyll a, $\mathrm{b}$, and $\mathrm{a}+\mathrm{b}$, carotenoids, and anthocyanins in "Aztec Fuji" apple.

\begin{tabular}{|c|c|c|c|c|c|c|}
\hline \multirow{2}{*}{ Treatment } & \multirow{2}{*}{$\begin{array}{c}\text { Proline } \\
\text { (mg/g dwt) }\end{array}$} & \multicolumn{3}{|c|}{$\begin{array}{l}\text { Chlorophyll } \\
\text { (mg/g dwt) }\end{array}$} & \multirow{2}{*}{$\begin{array}{l}\text { Carotenoids } \\
\text { (mg/gr dwt) }\end{array}$} & \multirow{2}{*}{$\begin{array}{c}\text { Anthocyanins } \\
\text { (mg/gr dwt) }\end{array}$} \\
\hline & & $\mathrm{a}$ & $\mathrm{b}$ & Total $(a+b)$ & & \\
\hline \multicolumn{7}{|l|}{ Rootstock } \\
\hline Nic 29 & $0.7779 \mathrm{a}^{\mathrm{x}}$ & $29.53 \mathrm{a}$ & $26.26 \mathrm{a}$ & $55.78 \mathrm{a}$ & $0.0177 \mathrm{a}$ & $0.0542 \mathrm{a}$ \\
\hline Bud 9 & $0.5047 \mathrm{~b}$ & $30.74 \mathrm{a}$ & $23.05 \mathrm{~b}$ & $53.79 \mathrm{~b}$ & $0.0178 \mathrm{a}$ & $0.0631 \mathrm{a}$ \\
\hline \multicolumn{7}{|l|}{ Tree Training } \\
\hline Central Leader & $0.7491 \mathrm{a}$ & $30.67 \mathrm{a}$ & $24.63 \mathrm{a}$ & $55.31 \mathrm{a}$ & $0.0176 \mathrm{a}$ & $0.0603 \mathrm{a}$ \\
\hline Tall Spindle & $0.5228 \mathrm{~b}$ & $29.54 \mathrm{~b}$ & $24.67 \mathrm{a}$ & $54.21 \mathrm{~b}$ & $0.0179 \mathrm{a}$ & $0.0568 \mathrm{a}$ \\
\hline \multicolumn{7}{|l|}{ Girdling $^{z}$} \\
\hline NOGD & $0.7965 \mathrm{a}$ & $30.71 \mathrm{a}$ & $26.66 \mathrm{a}$ & $57.37 \mathrm{a}$ & $0.0174 \mathrm{a}$ & $0.0599 \mathrm{a}$ \\
\hline BG15 & $0.5100 \mathrm{~b}$ & $28.81 \mathrm{a}$ & $22.29 \mathrm{~b}$ & $51.10 \mathrm{~b}$ & $0.0175 \mathrm{a}$ & $0.0627 \mathrm{a}$ \\
\hline SG15 & $0.6478 \mathrm{ab}$ & $30.95 a$ & $24.69 \mathrm{~b}$ & $55.64 \mathrm{a}$ & $0.0184 \mathrm{a}$ & $0.0521 \mathrm{a}$ \\
\hline
\end{tabular}

${ }^{z}$ Abbreviations: NOGD = no girdling (control); BG15 = bark girdling in 2015; SG15 = score girdling in 2015; BG1516 = bark girdling in 2015 and 2016 ; SG1516 = score girdling in 2015 and 2016. ${ }^{\mathrm{x}}$ Mean separation within columns in each group of treatments by LSD at 5\% level. No interaction existed among any treatments. 
Table 3. The influence of rootstock, canopy architectures, and cambium disconnection on leaf nitrogen, yield, and fruit weight in “Aztec Fuji” apple.

\begin{tabular}{|c|c|c|c|c|c|c|}
\hline \multirow{2}{*}{ Treatment } & \multicolumn{2}{|c|}{$\begin{array}{l}\text { Leaf N } \\
(\% \text { dwt })\end{array}$} & \multicolumn{2}{|c|}{$\begin{array}{c}\text { Yield } \\
(\mathrm{kg} / \text { tree })\end{array}$} & \multicolumn{2}{|c|}{$\begin{array}{l}\text { Fruit weight } \\
\text { (g) }\end{array}$} \\
\hline & 2015 & 2016 & 2015 & 2016 & 2015 & 2016 \\
\hline \multicolumn{7}{|l|}{ Rootstock } \\
\hline Nic 29 & $2.30 \mathrm{a}^{\mathrm{x}}$ & $2.33 \mathrm{a}$ & $46.1 \mathrm{a}$ & $47.3 \mathrm{a}$ & $238.4 \mathrm{a}$ & $246.6 \mathrm{a}$ \\
\hline Bud 9 & $2.19 \mathrm{~b}$ & $2.26 \mathrm{~b}$ & $25.3 \mathrm{~b}$ & $45.8 \mathrm{a}$ & $229.1 b$ & $230.5 \mathrm{~b}$ \\
\hline \multicolumn{7}{|l|}{ Tree Training } \\
\hline Central Leader & $2.29 \mathrm{a}$ & $2.27 \mathrm{a}$ & $38.8 \mathrm{a}$ & $43.4 \mathrm{~b}$ & $235.7 \mathrm{a}$ & $242.7 \mathrm{a}$ \\
\hline Tall Spindle & $2.20 \mathrm{~b}$ & $2.32 \mathrm{a}$ & $31.3 \mathrm{a}$ & $49.1 \mathrm{a}$ & $231.4 \mathrm{a}$ & $234.0 \mathrm{a}$ \\
\hline \multicolumn{7}{|l|}{ Girdling $^{z}$} \\
\hline NOGD & $2.30 \mathrm{a}$ & $2.30 \mathrm{~b}$ & $36.2 \mathrm{a}$ & $41.6 \mathrm{~b}$ & $213.5 \mathrm{~b}$ & $223.3 \mathrm{~b}$ \\
\hline BG15 & $2.16 \mathrm{~b}$ & $2.41 \mathrm{a}$ & $36.5 \mathrm{a}$ & $51.9 \mathrm{a}$ & $243.8 \mathrm{a}$ & $241.6 \mathrm{ab}$ \\
\hline SG15 & $2.28 \mathrm{a}$ & $2.32 \mathrm{~b}$ & $32.1 \mathrm{a}$ & $46.6 \mathrm{ab}$ & $240.0 \mathrm{a}$ & $236.0 \mathrm{ab}$ \\
\hline BG1516 & . & $2.17 \mathrm{c}$ & . & $45.0 \mathrm{ab}$ & . & $242.0 \mathrm{ab}$ \\
\hline SG1516 & . & $2.27 \mathrm{~b}$ & . & $50.3 \mathrm{a}$ & . & $249.3 \mathrm{a}$ \\
\hline \multicolumn{7}{|l|}{ Significance ${ }^{y}$} \\
\hline Rootstock & $* *$ & ** & ** & NS & $* *$ & ** \\
\hline Tree training & $* *$ & NS & NS & * & NS & NS \\
\hline Rootstock ${ }^{\star}$ tree training & NS & NS & NS & * & NS & NS \\
\hline Rootstock $^{\star}$ tree training ${ }^{\star}$ girdling & NS & NS & NS & NS & NS & NS \\
\hline
\end{tabular}

${ }^{\mathrm{z}}$ Abbreviations: NOGD = no girdling (control); BG15 = bark girdling in 2015; SG15 = score girdling in 2015; BG1516 = bark girdling in 2015 and 2016 ; SG1516 = score girdling in 2015 and 2016 . 'Significance: Significant at $1 \%$ level if shown by ${ }^{*}$, at $5 \%$ level if shown by ${ }^{*}$, and no significant if shown by NS. ${ }^{\mathrm{x}}$ Mean separation within columns in each group of treatments by LSD at $5 \%$ level or less.

\subsection{Rootstock Effect}

Leaves from terminal and side branches of trees on both "Bud 9" and "Nic 29" rootstocks had lower CI during early growing season (August 15, 2015 and June 30, 2016) than those in late season (October 16, 2015 and October 20, 2016) (Table 1), due to the declining trend of seasonal leaf nitrogen [8] and perhaps chlorophyll content. Side branches of trees on "Bud 9" had significantly higher CI (up to 5\%) than those on "Nic 29" rootstock during all sampling times in 2015 and 2016 (Table 1). In contrast, terminal branches of trees on "Nic 29" rootstock tended to have up to $6 \%$ higher CI than those on "Bud 9" in both 2015 and 2016. Terminal buds of trees on dwarf rootstocks, such as "Bud 9", grows slower and cease before those on more vigorous rootstocks such as "Nic 29" [3], perhaps leading to a higher distribution of nitrogen and chlorophyll in the side branches in trees on "Bud 9". Leaf samples were taken from terminal shoots, and leaves from trees on "Nic 29" had significantly (up to 5\%) higher concentration of N than those on "Bud 9" (Table 3). 
Leaves from terminal shoots of trees on "Nic 29" rootstock had 54\% higher proline, $14 \%$ higher chlorophyll $\mathrm{b}$, and about $4 \%$ higher total chlorophyll $(\mathrm{a}+\mathrm{b})$ those did those on "Bud 9" rootstock, perhaps due to their higher N concentrations (Table 2). The impact of rootstock on the actual total chlorophyll content of terminal shoots (Table 2) parallels the results found in their non-destructive chlorophyll index measurements (Table 1). However, there was no significant difference between two rootstocks for the levels of carotenoids and anthocyanins.

Trees on "Nic 29" also had up to 7\% larger average (heavier) fruit than those on "Bud 9" in both 2015 and 2016, despite their 83\% higher yield in 2015 (Table 3 ). Usually heavier yield is associated with smaller fruit size. However, trees in all treatments were thinned at about $15 \mathrm{~cm}$ spacing at the time of hand thinning. Therefore, higher yield and larger fruit size in trees on "Nic 29" compared to those on "Bud 9" is due to their larger canopy, leading to a higher leaf/fruit ratio in trees on "Nic 29". It is extremely difficult to determine true effects of rootstock on the scion cultivar fruit quality and other characteristics. This is mainly because confounding effects such as rate of light penetration, crop load, and tendency of biennial bearing can confuse the results. Similar to our assessment, Autio [54] experienced the same challenge in evaluating the impact of six rootstocks on fruit quality attributes of "Delicious" apple. However, he concluded that fruit size consistently was largest from trees on "M.9" EMLA and smallest from trees on “OAR 1" rootstocks.

\subsection{Tree Architecture Effect}

Trees with CL architecture had up to 6\% higher terminal shoot chlorophyll index than did those with a TS system in both 2015 and 2016 (Table 1). However, side branch chlorophyll indices in these two training systems were statistically similar (Table 1). Also, Trees with a CL system had $43 \%$ higher proline content and $4 \%$ higher chlorophyll a than did those with a TS training system in 2015 (Table 2). While, there were no significant differences between two training systems, nor between carotenoids and anthocyanin concentrations. The impact of training system on the actual total chlorophyll content of terminal shoots (Table 2) parallels the results found in their non-destructive chlorophyll index measurements (Table 1). In addition, Trees with a CL system in 2015 measurement had $4 \%$ higher leaf $\mathrm{N}$ as compared to trees with TS system. Nevertheless, trees with a TS training had 13\% higher yield than those with a CL training (49.1 vs. $43.3 \mathrm{~kg} /$ tree), while fruit weight was similar in both tree training systems (Table 3). There was a significant interaction between rootstock and tree architecture for yield per tree in 2016 (Table 3). In this interaction, trees on "Nic 29" with a CL training had significantly lower yield $(39.9 \mathrm{~kg} / \mathrm{tree})$ than those on "Nic 29 " with a TS tree training that had $53.9 \mathrm{~kg} /$ tree in 2016 . Trees on "Nic 29" with a CL training had denser and darker canopies (personal observation), resulting in excessive shading and lower fruit bud formation, and thus lower yield than those on "Nic 29" with a TS training. 
Trees on "Nic 29", with either a CL or TS training system, needed more time for training and pruning, and this issue should be considered when choosing this rootstock. "Aztec Fuji" trees on "Nic 29" rootstock can be suitable for planting at farther than $0.9 \mathrm{~m}$ spacing between trees in a row and in the lighter soil in the region. "Bud 9" is also a suitable rootstock for "Aztec Fuji" apple if extra-large fruit size is not the main objective of apple production.

\subsection{Girdling Effect}

Bark girdling in 2015 (BG15) significantly reduced CI in terminal branches than NOGD (up to 7\%). Also, bark girdling in 2015, repeated in 2016 (BG1516) treatments reduced leaf $\mathrm{N}$ concentrations than all other treatments (up to $11 \%$ ) (Table 2). The total leaf chlorophyll content and chlorophyll b in bark-girdled trees was also lower than those of non-girdled (up to $12 \%$ and $20 \%$ in $\mathrm{Chl} \mathrm{a}+\mathrm{b}$ and $\mathrm{Chl} \mathrm{b}$, respectively) (Table 2). Reduction of leaf chlorophyll as a result of bark girdling is in general agreement with previous reports [20] [30] [41] [42] [44] [45]. Girdling reduced leaf chlorophyll content in citrus trees, perhaps because girdling increases carbohydrates, resulting in changes to PSII system [42]. In addition, our results revealed that bark girdling (BG15) decreased proline content of leaves as compared to those on non-girdled (56\%) and score-girdled (27\%) trees (Table 2). Trees receiving BG15 or BG1516 had significantly lower leaf $\mathrm{N}$ than other treatments (up to $6.5 \%$ and $11 \%$ for BG15 and BG1516, respectively) (Table 2) which resulted in improved fruit color in these trees (data not shown). The results are in agreement with Schechter et al. [28] who reported that nutrient concentrations; including $\mathrm{N}$ in leaves on girdled non-fruiting limbs were generally lower than those in the other treatments. The impact of girdling in their non-fruiting "Sturdeespur Delicious" agreed with our results in fruiting "Aztec Fuji" apples. Impacts of girdling on nutrient partitioning in apple fruit tissue on different rootstocks warrant further investigation. Also, better color in the fruit from apple trees with lower leaf $\mathrm{N}$ was previously reported by Fallahi et al. [19], which can be due to lower chlorophyll content in the skin of these fruit. Girdling can reduce resistance to cold stress in grape vines [12] and tree fruit (Fallahi, data not published). Thus, lower proline content of trees receiving a bark girdling treatment in 2015-girdled trees may make these girdled trees susceptible to extreme sub-freezing temperatures, and the authors have repeatedly observed this situation (data not shown).

Girdling treatments in 2015 did not affect yield per tree in 2015. This result was expected because flowers of 2015 crop were initiated, and fruit of this season were already set before we applied our girdling treatments in May 2015. However, trees with BG15 or SG1516 treatments had significantly (21\% to $25 \%$ ) higher yield in 2016 compared to those with NOGD treatment (Table 3), because girdling or scoring in 2015 resulted in more fruit initiation and fruit set, leading to higher crop in 2016. Enhancing yield/tree by girdling is in general agreement with the result of Ibrahim et al. [41] on Washington navel orange trees.

Fruit weight in 2015 and 2016 was affected by girdling treatments. In 2015, 
both bark and score girdled trees (BG15 and SG15) had 14\% and 12.5\% (respectively) higher fruit weight than non-girdled trees (Table 3). However, in 2016 only trees receiving repeated of score girdling on the same tree (SG1516) had about $12 \%$ higher fruit weight than NOGD (Table 3). These results suggest that carbohydrates accumulation is increased in the girdled trees. Similar to our results, Nguyen \& Chung [55] reported that a simple S-shape scoring increased fruit weight and size in "Wax" apple. Based on our two-year data, we conclude that score and bark girdling in one year is sufficient to increase fruit weight of the current year and the yield in the following year. However, if both fruit weight and higher yield are the critical objectives of fruit production, annual bark scoring should be practiced in each year. Similarly, Mostafa \& Saleh [36] found that girdling increased fruit weight in "Balady" mandarin.

Trees, which are bark girdled, needed about 6 weeks to heal. Trees, which are score girdled need about 3 weeks to heal. Many apple growers, particularly in the humid regions, are concerned that girdling or scoring during early growing season might introduce fireblight bacteria through the wounded areas. Although we did not observe any sign of fireblight incident in theses experimental trees, one can postpone the girdling or scoring to late June or early July when fire blight inoculum is reduced in the orchard. This practice must be tested in each apple growing region before it is widely recommended to growers. It is extremely important to allow enough time to the girdling or scoring wounds to heal to avoid possible freeze damage. In general, reduced leaf $\mathrm{N}$ concentrations of girdled trees may reduce photosynthesis in the long-term. The positive effects of girdling on yield and fruit weight may encourage some orchardists to use this method in fruit crop trees; however they should be aware of possible cold damage if temperatures plunge down to temperatures below which cells are acclimated.

\section{Conclusion}

From our 2-year study, we concluded that leaves from terminal and side branches of trees on both "Bud 9" and "Nic 29" rootstocks had lower CI during early growing season than those in late season. Side branches of trees on "Bud 9" had higher CI than those on "Nic 29" rootstock. In contrast, terminal branches of trees on "Nic 29" rootstock tended to have higher CI than those on "Bud 9" in both 2015 and 2016. Trees with CL architecture had higher terminal shoot chlorophyll index than did those with a TS system. Also, leaves from trees with a CL system had higher proline and chlorophyll a than those with a TS training system. Frequency of girdling and scoring practices in combination with different rootstocks and training systems had impacts on growth, yield, fruit size, chlorophyll index and proline. However, there may be some major long-term effects of girdling on tree performance, cold tolerance, and biennial bearing and thus, a longer-term investigation is warranted.

\section{Acknowledgements}

We thank the Idaho Apple Commission and the Idaho Agricultural Experiment 
Station for their financial support of this project. This work was supported in part by U.S. Department of Agriculture National Institute of Food and Agriculture Specialty Crop Research Initiative project "AppleRoot2Fruit: Accelerating the development, evaluation and adoption of new apple rootstocks" (2016-51181-25406). We are also thankful to the C \& O Nursery in Washington State for providing the experimental trees.

\section{Conflicts of Interest}

The authors declare no conflicts of interest regarding the publication of this paper.

\section{References}

[1] Autio, W.R., Hayden, R.A., Micke, W.C., et al. (1996) Rootstock Affects Ripening, Color, and Shape of "Starkspur Supreme Delicious" Apples in the 1984 NC-140 Cooperative Planting. Fruit Varieties Journal, 50, 45-53.

[2] Fallahi, E., Fallahi, B., Shafii, B., et al. (2007) Water Use, Tree Growth, and Leaf Mineral Nutrients of Young "Fuji" Apples as Influenced by Different Irrigation Systems. Acta Horticulturae, 721, 63-70.

https://doi.org/10.17660/ActaHortic.2006.721.7

[3] Fallahi, E., Fallahi, B. and Shafii, B. (2013) Irrigation and Rootstock Influence on Water Use, Tree Growth, Yield, and Fruit Quality at Harvest at Different Ages of Trees in 'Pacific Gala' Apple. HortScience, 48, 588-593. https://doi.org/10.21273/HORTSCI.48.5.588

[4] Fallahi, E., Arzani, K. and Fallahi, B. (2013) Long-Term Leaf Mineral Nutrition in "Pacific Gala" Apple (Malus domestica) as Affected by Rootstock Type and Irrigation System during Six stages of Tree Development. The Journal of Horticultural Science \& Biotechnology, 88, 685-692. https://doi.org/10.1080/14620316.2013.11513025

[5] Fallahi, E., Fallahi, B., Kiester, M., et al. (2018) Cambium Disconnection, Rootstock, and Canopy Training Impacts on Growth and Leaf Mineral Nutrients in "Aztec Fuji” Apple. International Journal of Fruit Science, 19, 231-245. https://doi.org/10.1080/15538362.2018.1559119

[6] Chun, I.J., Fallahi, E., Colt, W.M., et al. (2001) Effects of Rootstocks and Microsprinkler Fertigation on Mineral Concentrations, Yield, and Fruit Color of "BC-2 Fuji” Apple. Journal of the American Pomological Society, 55, 197-205.

[7] Fallahi, E., Colt, W.M. and Fallahi, B. (2001) Optimum Ranges of Leaf Nitrogen for Yield, Fruit Quality, and Photosynthesis in "BC-2 Fuji" Apple. Journal of the American Pomological Society, 55, 68-75.

[8] Fallahi, E., Chun, I.J. and Neilsen, G.H. (2001) Effects of Three Rootstocks on Photo-Synthesis, Leaf Mineral Nutrition, and Vegetative Growth of "BC-2 Fuji” Apple Trees. Journal of Plant Nutrition, 24, 827-834. https://doi.org/10.1081/PLN-100103776

[9] Clements, J. (2011) "Mini” Apple Orchard Systems Trial: A Comparison of Central-Leader, Vertical-Axis, and Tall-Spindle Apple Orchard Systems on Three Different Rootstocks. Fruit Notes, 76, 10-13.

[10] Stone, E.L. (1974) The Communal Root System of Red Pine: Growth of Girdled Trees. Forest Science, 20, 294-305. 
[11] Fajstavr, M., Giagli, K., Vavrčík, H., et al. (2017) The Effect of Stem Girdling on Xylem and Phloem Formation in Scots Pine. Silva Fennica, 51, Article ID: 1760. https://doi.org/10.14214/sf.1760

[12] Fallahi, E., Tehranifar, A. and Gharaghani, A. (2017) Cluster Management to Improve Berry Quality in Young "Alborz" Table Grape in the Intermountain West Region, USA. International Journal of Fruit Science, 17, 349-357. https://doi.org/10.1080/15538362.2017.1315629

[13] Lewis, L.N. and McCarty, C.D. (1973) Pruning and Girdling of Citrus. In: Reuther W., Ed., The Citrus Industry, Vol. III, University of California, Berkeley.

[14] Rivas, F., Fornes, F. and Agustí, M. (2008) Girdling Induces Oxidative Damage and Triggers Enzymatic 21. Silva Fennica, 51, Article ID: 1760.

[15] Vemmos, S.N., Papagiannopoulou, A. and Coward, S. (2012) Effects of Shoot Girdling on Photosynthetic Capacity, Leaf Carbohydrate, and Bud Abscission in Pistachio (Pistaciavera L.). Photosynthetica, 50, 35-48. https://doi.org/10.1007/s11099-012-0003-0

[16] Weinburger, J.H. and Cullinan, F.P. (1932) Further Studies on the Relation between Leaf Area and Size of Fruit, Chemical Composition, and Fruit Bud Formation in Elberta Peaches. Proceedings of the American Society for Horticultural Science, 29, 23-27.

[17] Agusti, M., Andreu, I., Juan, M., et al. (1998) Effects of Ringing Branches on Fruit Size and Maturity of Peach and Nectarine Cultivars. The Journal of Horticultural Science and Biotechnology, 73, 537-540. https://doi.org/10.1080/14620316.1998.11511011

[18] Day, K.R. and DeJong, T.M. (1990) Girdling of Early Season "Mayfire" Nectarine Trees. Journal of Horticultural Science, 65, 529-534. https://doi.org/10.1080/00221589.1990.11516089

[19] Fallahi, E., Richardson, D.G., Westwood, M.N., et al. (1985) Relationships among Mineral Nutrition, Ethylene and Post-Harvest Physiology in Apples on Six Rootstocks. Scientia Horticulturae, 25, 163-185. https://doi.org/10.1016/0304-4238(85)90087-1

[20] Yamane, T. and Shibayama, K. (2006) Effects of Trunk Girdling and Crop Load Levels on Fruit Quality and Root Elongation in "Aki Queen” Grapevines. Journal of the Japanese Society for Horticultural Science, 75, 439-444. https://doi.org/10.2503/jjshs.75.439

[21] Noel, A.R.A. (1970) The Girdled Tree. The Botanical Review, 36, 162-195. https://doi.org/10.1007/BF02858959

[22] Schumacher, R.F., Fankhauser, F. and Stadler, W. (1986) Influence of Growth Regulators, Ringing and Root Cutting on Apple Quality and Physiological Disorders. Acta Horticulturae, 179, 731-742. https://doi.org/10.17660/ActaHortic.1986.179.125

[23] Wargo, J.M., Merwin, I.E. and Watkins, C.B. (2004) Nitrogen Fertilization, Midsummer Trunk Girdling, and AVG Treatments Affect Maturity and Quality of "Jonagold" Apples. HortScience, 39, 493-500. https://doi.org/10.21273/HORTSCI.39.3.493

[24] Autio, W.R. and Greene, D.W. (1994) Effects of Growth Retarding Treatments on Apple Tree Growth, Fruit Maturation and Fruit Abscission. Journal of Horticultural Science, 69, 653-664. https://doi.org/10.1080/14620316.1994.11516497

[25] Greene, D.W. and Lord, W.J. (1983) Effects of Dormant Pruning, Summer Pruning, Scoring and Growth Regulators on Growth, Yield and Fruit Quality of "Delicious" 
and "Cortland" Apple Trees. Journal of the American Society for Horticultural Science, 108, 590-595.

[26] Hennerty, M.J. and Forshey, C.G. (1971) Effects of De-Fruiting, Scoring, Defoliation and Shading on Carbohydrate Content of "Golden Delicious" Apple Trees. Journal of Horticultural Science, 46, 153-161. https://doi.org/10.1080/00221589.1971.11514394

[27] Hoying, S.A. and Robinson, T.L. (1992) Effects of Chain Saw Girdling and Root Pruning of Apple Trees. Acta Horticulturae, 322, 167-172. https://doi.org/10.17660/ActaHortic.1992.322.18

[28] Schechter, I., Proctor, J.T.A. and Elfving, D.C. (1994) Apple Fruit Removal and Limb Girdling Affects Fruit and Leaf Characteristics. Journal of the American Society for Horticultural Science, 119, 157-162. https://doi.org/10.21273/JASHS.119.2.157

[29] Raffo, M.D., Calvo, P., De Angelis, V., et al. (2011) Effects of Trunk Girdling, on Fruit Productions, Fruit Size, and Tree Vigor on "Bartlett" Pears in Rio Negro and Neuquén Valley, Argentina. Acta Horticulturae, 909, 645-650.

https://doi.org/10.17660/ActaHortic.2011.909.78

[30] Davie, S.J., Stassen, P.J.C.M., Walt, V.D., et al. (1995) Girdling Avocado Trees for Improved Production. South African Avocado Growers' Association Yearbook, 18, 51-53.

[31] Reynolds, A.G. and de Savigny, C. (2004) Influence of Girdling and Gibberellic Acid on Yield Components, Fruit Composition, and Vestigial Seed Formation of "Sovereign Coronation" Table Grapes. HortScience, 39, 541-544. https://doi.org/10.21273/HORTSCI.39.3.541

[32] Steyn, W.J., Ungerner, F.U. and Theron, I.K. (2008) Scoring and Girdling, But Not GA3, Increase Yield without Decreasing Return Bloom in "Triumph" Persimmon. HortScience, 43, 2022-2026. https://doi.org/10.21273/HORTSCI.43.7.2022

[33] Fernandez-Escobar, R., Martin, R., Lopez-Rivares, P., et al. (1987) Girdling as a Means of Increasing Fruit Size and Earliness in Peach and Nectarine Cultivars. Journal of Horticultural Science, 62, 463-468. https://doi.org/10.1080/14620316.1987.11515807

[34] Agusti, M., Gariglio, N., Juan, M., et al. (2005) Effect of Branch Scoring on Fruit Development in Loquat. The Journal of Horticultural Science and Biotechnology, 80, 370-374. https://doi.org/10.1080/14620316.2005.11511946

[35] Furr, J.R., Reece, P.C. and Hrnciar, G. (1945) Nitrogen Absorption of Ringed Orange Trees in Sand Culture. Proceedings of the American Society for Horticultural Science, 46, 51-54.

[36] Chen, D., Kessler, B. and Monselise, S.P. (1964) Studies on Water Regime and Nitrogen Metabolism of Citrus Seedlings Grown under Water Stress. Plant Physiology, 39, 379-386. https://doi.org/10.1104/pp.39.3.379

[37] Biancucci, M., Mattioli, R., Moubayidin, L., et al. (2015) Proline Affects the Size of the Root Meristematic Zone in Arabidopsis. BMC Plant Biology, 15, 263. https://doi.org/10.1186/s12870-015-0637-8

[38] Dar, M.I., Naikoo, M.I., Rehman, F., et al. (2016) Proline Accumulation in Plants: Roles in Stress Tolerance and Plan Development. In: Iqbal, N., et al., Eds., Osmolytes and Plants Acclimation to Changing Environment. Emerging Omics Technologies, Springer, Berlin, 155-166. https://doi.org/10.1007/978-81-322-2616-1_9

[39] Yelenosky, G. (1979) Accumulation of Free Proline in Citrus Leaves during Cold Hardening of Young Trees in Controlled Temperature Regimes. Plant Physiology, 
64, 425-427. https://doi.org/10.1104/pp.64.3.425

[40] Okumoto, S., Funck, D., Trovato, D.M., et al. (2016) Editorial: Amino Acids of the Glutamate Family: Functions beyond Primary Metabolism. Frontiers in Plant Science, 7, 318. https://doi.org/10.3389/fpls.2016.00318

[41] Ibrahim, M.M., Mohamed, A.O., Mohamed, A.H., et al. (2016) Effect of Some Girdling Treatments on Fruiting Behavior and Physio-Chemical Properties of Washington Navel Orange Trees. Journal of Agriculture and Veterinary Sciences, 9, 58-65.

[42] Rivas, F., Gravina, A. and Agusti, M. (2007) Girdling Effects on Fruit Set and Quantum Yield Efficiency of PSII in Two Citrus Cultivars. Tree Physiology, 27, 527-535. https://doi.org/10.1093/treephys/27.4.527

[43] Mostafa, E.A.M. and Saleh, M.M.S. (2006) Response of "Balady" Mandarin Trees to Girdling and Potassium Sprays under Sandy Soil Conditions. Research Journal of Agriculture and Biological Sciences, 2, 137-141.

[44] Tang, G.L., Li, X.Y., Lin, L.S., et al. (2015) Girdling-Induced Alhagi sparsifolis and Chlorophyll Florescence Changes. Photosynthetica, 53, 585-596. https://doi.org/10.1007/s11099-015-0148-8

[45] Proietti, P. (2003) Changes in Photosynthesis and Fruit Characteristics in Olive in Response to Assimilate Availability. Photosynthetica, 41, 559-564. https://doi.org/10.1023/B:PHOT.0000027520.12822.de

[46] Washington State University (2019) Washington State University Tree Fruit Research and Extension Center. http://www.tfrec.wsu.edu

[47] Allen, R.G., Pereira, L.S., Raes, D., et al. (1998) Crop Evapotranspiration. Guidelines for Computing Crop Water Requirements. FAO Irrigation and Drainage Paper 56. FAO, Rome.

[48] Proebsting, E. (1994) Strategy Development for Managing Drought. In: Williams, K.M. and Ley, T.W., Eds., Tree Fruit Irrigation, Good Fruit Grower, Yakima, Washington DC, 39-50.

[49] Mahdavi, S. and Fallahi, E. (2016) Drought and Biostimulant Impacts on Important Attributes of Perennial Ryegrass for Orchard and Vineyard Floor in the Intermountain West Region of the United States. Journal of the American Pomological Society, 70, 216-223.

[50] Mahdavi, S., Kafi, M., Fallahi, E., et al. (2017) Drought and Biostimulant Impacts on Mineral Nutrients, Ambient and Reflected Lightbased Chlorophyll Index, and Performance of Perennial Ryegrass. Journal of Plant Nutrition, 40, 2248-2258. https://doi.org/10.1080/01904167.2016.1237650

[51] Bates, L., Waldren, R.P. and Teare, I.D. (1973) Rapid Determination of Free Proline for Water-Stress Studies. Plant Soil, 39, 205-207. https://doi.org/10.1007/BF00018060

[52] Arnon, D.I. (1949) A Copper Enzyme Is Isolated Chloroplast Oxidase in Beta vulgaris. Plant Physiology, 24, 1-15. https://doi.org/10.1104/pp.24.1.1

[53] Sims, D.A. and Gamon, J.A. (2002) Relationships between Leaf Pigment Content \& Spectral Reflectance across a Wide Range of Species, Leaf Structures \& Developmental Stages. Remote Sensing of Environment, 81, 337-354. https://doi.org/10.1016/S0034-4257(02)00010-X

[54] Autio, W.R. (1991) Rootstock Affects Ripening and Other Qualities of "Delicious" Apples. Journal of the American Society for Horticultural Science, 116, 378-382. https://doi.org/10.21273/JASHS.116.3.378 
[55] Nguyen, M.T. and Chung, Y.R. (2012) Effect of s-Girdling on Fruit Growth and Fruit Quality of Wax Apple. International Journal of Agricultural and Biological Engineering, 6, 1064-1069. 